\title{
Relationship between Service Quality on Public Health Center and Patient Satisfaction
}

\author{
Fuad Husain Akbar ${ }^{1} \&$ Muhammad Tegar Jaya ${ }^{2}$ \\ ${ }^{1}$ Department of Dental Public Health, Faculty of Dentistry, Hasanuddin University, Makassar, Indonesia \\ ${ }^{2}$ Clinical Student, Faculty of Dentistry, Hasanuddin University, Makassar, Indonesia \\ Correspondence: Fuad Husain Akbar, Department of Dental Public Health, Faculty of Dentistry, Hasanuddin \\ University, Makassar, Indonesia. Tel: 62-812-4342-2362.
}

\author{
Received: March 21, 2017 Accepted: April 7, 2017 Online Published: April 10, 2017 \\ doi:10.5539/gjhs.v9n7p96 URL: https://doi.org/10.5539/gjhs.v9n7p96
}

\begin{abstract}
Introduction: The aim of this study was to examine the relationship between services quality on public health center and patient satisfaction in Kutai Kartanegara Regency, Indonesia.

Method: This research used pilot pathfinder survey, which was done on February $23^{\text {rd }}-25^{\text {th }} 2017$ in Kutai Kartanegara Regency, Indonesia. Two questionnaires were used in the study. During the data collection, there were 192 patients from the health service center, it was consisted two locations representing the urban and rural area in order to describe the quality of health service towards the patients' satisfaction. In order to investigate the correlation between the quality of health service and patient satisfaction, Pearson correlation test was conducted.

Result: The highest score regarding of the service quality was on the dimension of the doctors and pharmacy were $99.5 \%$. The lowest level of patients' satisfaction on assurance and empathy dimension were $10.4 \%$. There was a significance between the service quality of the doctors, nurses, pharmacy, and the administrators towards the patients' satisfaction. The highest score of the coefficient correlation on the nurse dimension was 0.273 , which means that the nurses were giving good services quality and it affects the people's satisfaction.

Conclusion: A good service quality believes would affect the people's satisfaction which generally affects people's decision to choose health service provider. Health service center is expected to increase their environmental condition, and the professionalism of the nurses and registration officers in terms of their awareness and performance in order to create better services.
\end{abstract}

Keywords: quality of care, patient satisfaction, Indonesia

\section{Introduction}

Health is the prosperous state of body, soul, and social which enables individuals to live productively in social and economical aspects. In terms of reaching the goals, comprehensive health effort that can be afforded by all society is done, including the field of dental health (Marine et al., 2014). Based on Indonesian Law Number 36 of 2009 about health regulations, it is stated that everyone has equal rights in obtaining access health care, safe, qualified, affordable health service, has the rights to independently and responsibly decide the health service that they need. Meanwhile, the government is responsible for guaranteeing the healthy right to live for their people. Most people argue that the service provided by the state health service center has not been absolutely compatible with their expectation that it generates dissatisfaction; whereas the satisfaction of the users is the parameter of the quality of health service (Ministry of Health, 2014; Hidayat, 2016).

Patients are the important aspect in seeing the service quality provided in the field of health. Sometimes the service provided by health service providers and private dental clinics is still considered inadequate. There are several factors causing people feel uncomfortable of getting treatments such as hesitation of the dentists' capability to diagnose and give treatments towards the patients' illnesses, less sophisticated and less modern facilities and technology that are used, the system of treatment that takes too long, and lacking hospitality and skills of the medical resources. The success of the health service centers is influenced by the effectiveness and efficiency of the service related to the patients (Tanudjaya, 2014; Devi et al., 2016).

By the time, the increase of awareness and the importance of dental and oral health will evoke the self-satisfaction 
of the patients. Patients' satisfaction towards the dental and oral health service is the comparison between the perception towards the service obtained and the patient's expectation before obtaining the service. If the expectation is fulfilled, it means that such service has given an incredible quality and will also evoke a high level of satisfaction (Mariane et al., 2014). The aspect observed from the quality of service includes the tangibles of the dental clinic, reliability aspect, fast responsiveness aspect, assurance aspect, and empathy aspect (Tanudjaya, 2014).

Patients' experience and satisfaction towards dental treatment are an important factor to increase dental and oral health. The patients' perception towards the service quality is believed to influence the patients' satisfaction positively which indicates that the patients' satisfaction is a result obtained from the provided treatments. The previous study by Mariane in Bahu Public Health Service in Manado stated that the medical service relates to the ultimate aspects such as appropriateness, effectiveness, and benefits of the service for the patients. From the result of her research, the level of patients' satisfaction based on the quality of the medical service obtained an average score of $89.1 \%$ with the category of strongly satisfied. The same situation is also found on a research conducted by Meymand in Iran which the average score obtained shows that $80 \%$ of the respondents felt satisfied with the quality provided by the hospital. Most of the questions in the research questionnaire ask about the service obtained, the response towards the patients' needs, providing information, explanation about the existing problems, and effective communication (Marine et al., 2014; Edman et al., 2017; Bahari \& Azizan, 2013; Meymand et al., 2017).

On the health treatment, the patients' perception is considered as the main indicator in evaluating the service quality. Patients' satisfaction depends on their perception during the utilization of the health service. Based on previous research, in order to measure the service quality in health service center, four variables were used; doctors' service, nurses' service, operational quality, and the entire service quality. on the other hand, the service centers provide the same kind of service for the patients; however, they cannot give the same quality of service. Therefore, all health service centers are obliged to provide all diagnostic and therapeutic services as much as possible due to the fact that the high level of patients' satisfaction relates to a better health (Gopal \& Bedi, 2014; Farooq et al., 2012; Asefa et al., 2014; Gharibi et al., 2016).

The limitedness of medical resources in Kutai Kartanegara Regency based on the National Statistics data influences the service quality and affects the level of people's satisfaction. Despite the limited number of health service center which is not comparable to the area complicates the people to obtain health service. It is made more difficult by the unavailability of public transportation that the people only rely on private transportation such as motorcycle to visit the public health service center. Looking at the existing situation, the researcher is interested in finding out the relation between the quality of health service and the level of people's satisfaction in Kutai Kartanegara Regency, Indonesia. (National Statistics, 2016; Department of health East Borneo, 2013).

\section{Method}

This research used pilot pathfinder survey by estimating the size of the sample based on age category in the location representing urban and rural area (World Health Organization, 2013). The data was collected in Kutai Kartanegara Regency, East Borneo, Indonesia on February $23^{\text {rd }}-25^{\text {th }} 2017$. The subject of the research was the citizen of Tenggarong and Samboja Districts, Kutai Kartanegara Regency, who were in the age of $\geq 18$ years old and who had obtained medical treatments in health service center. The total of the respondents were 214 people; 103 respondents were in the urban category and 111 respondents were in rural category. Only the respondents who answered all the items in the demography questionnaire and the questionnaire of satisfaction towards service and service quality were included, that the final number of the sample was 192; 95 respondents were in the urban category and 97 respondents were in rural category.

The quality of the service was measured using SERVQUAL (Services Quality) questionnaire developed by Parasuraman. There were 5 dimensions of service (registration, doctor, nurse, pharmacy, and environment of health service center) with the total of 56 questions. Each question had 5 alternative answers which included: (Code $5=$ excellent, $4=$ very good, $3=$ good, 2 = fair, and $1=$ poor), (Parasuraman et al., 1988). The Satisfaction of the Health Service was measured using the questionnaire of Dena Ali which consisted of 5 dimensions (dimensions of tangibles, empathy, responsiveness, assurance, and reliability) and 22 questions which had 5 alternative answers (Code $5=$ strongly satisfied, $4=$ satisfied, $3=$ neutral, $2=$ dissatisfied, 1 = strongly dissatisfied), (Ali, 2016).

The score was given in order to determine the highest and lowest scores. The distribution is useful in avoiding the data which was not normally distribution. The score was given according to Likert study. The appraisal of 5 dimensions of health service quality of 56 questions had the maximum score of 280 and the minimum score of 56 . The score which was less than 112 was categorized as poor, while score which was more than 112 was categorized 
as good. The appraisal of 5 dimensions of satisfaction towards health service of 22 questions had the maximum score of 110 and the minimum score of 22 . The score which was less than 66 was categorized as dissatisfied, while score which was more than 66 was categorized as satisfied.

The data was analyzed using SPSS 23 program and was analyzed using Pearson correlation test used to measure the strength and the linear relation direction from the two variables. The data serving in tables.

\section{Result}

The demographic characteristics of the patients participating in the study are summarized in Table 1 .

Table 1. Demographic characteristics of the respondents

\begin{tabular}{|c|c|c|c|}
\hline Demographic variables & & Frequency & Percent \\
\hline \multirow{3}{*}{ Gender } & Male & 48 & 25 \\
\hline & Female & 144 & 75 \\
\hline & Total & 192 & 100 \\
\hline \multirow{3}{*}{ Age } & Adult age group 18-44 & 116 & 60.3 \\
\hline & Adult age group $\geq 45$ & 76 & 39.7 \\
\hline & Total & 192 & 100 \\
\hline \multirow{6}{*}{ Education } & No education & 6 & 3.1 \\
\hline & Primary school & 29 & 15.1 \\
\hline & Junior high school & 27 & 14.1 \\
\hline & Senior high school & 100 & 52.1 \\
\hline & Bachelor's degree & 30 & 15.6 \\
\hline & Total & 192 & 100 \\
\hline \multirow{4}{*}{ Distance from house to public health center } & $0-5 \mathrm{~km}$ & 144 & 75 \\
\hline & $6-10 \mathrm{~km}$ & 25 & 13 \\
\hline & $\geq 11 \mathrm{~km}$ & 23 & 12 \\
\hline & Total & 192 & 100 \\
\hline \multirow{4}{*}{ Transportation to public health center } & Walk & 14 & 7.3 \\
\hline & Motorcycle & 163 & 84.9 \\
\hline & Car & 15 & 7.8 \\
\hline & Total & 192 & 100 \\
\hline
\end{tabular}

Table 2. The distribution of respondents answer based on health services quality on public health center

\begin{tabular}{|c|c|c|c|c|}
\hline \multirow{3}{*}{ Quality of health services } & \multicolumn{4}{|c|}{ The answer of respondents based on service quality } \\
\hline & \multicolumn{2}{|l|}{ Good } & \multicolumn{2}{|l|}{ Poor } \\
\hline & Frequency & Percent & Frequency & Percent \\
\hline 1. Registration & 188 & 98.0 & 4 & 2.0 \\
\hline 2. Doctor & 191 & 99.5 & 1 & 0.5 \\
\hline 3. Nurse & 187 & 97.4 & 5 & 2.6 \\
\hline 4. Pharmacy & 191 & 99.5 & 1 & 0.5 \\
\hline 5. Environment of health service center & 183 & 95.3 & 9 & 4.7 \\
\hline
\end{tabular}

According to Table 2, the health services quality was assessed based on the dimension of registration, doctors, nurses, pharmacy, and the environment of health service center. From the five dimension assessed regarding the 
quality of health service, the question which gained the highest number of 'good' answers was the one on the dimension of doctors and pharmacy, in which $99.5 \%$ of the respondents on the dimension felt that the service was good. However, the dimension of the environment in the health service center obtained the highest number of 'poor' answers, was 9 respondents $(4.7 \%)$. Besides, the dimension of registration and nurses also obtained poor answers from the respondents, was $2.0 \%$ and $2.6 \%$.

Table 3. The distribution of respondents answer based on satisfaction of health services on public health center

\begin{tabular}{clllll}
\hline \multirow{2}{*}{ Satisfaction of health services } & \multicolumn{2}{l}{ The answer of respondents based on satisfaction } \\
\cline { 3 - 6 } & & Satisfied & & \multicolumn{2}{l}{ Dissatisfied } \\
\cline { 3 - 5 } \cline { 3 - 5 } & Frequency & Percent & & Frequency & Percent \\
\hline 1. & Assurance & 172 & 89.6 & 20 & 10.4 \\
2. & Empathy & 172 & 89.6 & 20 & 10.4 \\
3. & Responsiveness & 176 & 91.7 & 16 & 8.3 \\
4. & Tangibles & 177 & 92.2 & 15 & 7.8 \\
5. & Reliability & 177 & 92.2 & 15 & 7.8 \\
\hline
\end{tabular}

The satisfaction of health service was assessed from 22 questions which were categorized in five dimensions; assurance, empathy, responsiveness, tangibles, and reliability. The question which obtained the highest number of 'satisfied' answers was the dimension of tangibles and reliability in which 177 (92.2\%) of the respondents felt satisfied. The dimensions of assurance and empathy obtained the highest number of 'dissatisfied' answers was 20 $(10.4 \%)$ respondents. Meanwhile, the dimension of responsiveness obtained the second smallest number of respondents who felt dissatisfied, was $16(8.3 \%)$ respondents.

Table 4. Correlation between the dimensions of health service quality and patient satisfaction

\begin{tabular}{lll}
\hline $\begin{array}{l}\text { Correlation between the dimensions of health service quality } \\
\text { and patient satisfaction }\end{array}$ & P-value & The correlation coefficient \\
\hline 1. Registration & $0.001^{*}$ & 0.244 \\
2. Doctor & $0.001^{*}$ & 0.247 \\
3. Nurse & $0.000^{*}$ & $0.273^{\beta}$ \\
4. Pharmacy & $0.004^{*}$ & 0.205 \\
5. Environment of health service center & 0.202 & 0.092 \\
\hline
\end{tabular}

Note. ${ }^{*}=$ significance $(\mathrm{p}<0.05), \beta=$ the highest score of coefficient correlation.

From Table 4, it shows that the significance score was on the dimensions of registration 0.001 , doctors 0.001 , nurses 0.000 , and pharmacy 0.004 . The significance score of the variable was $\mathrm{p}<0.05$, which means that registration, doctors, nurses, and pharmacy significantly influenced the level of people's satisfaction. Pearson analysis showed that the highest correlation relation was on the nurses $(0.273)$ which mean that nurses had a good quality of service and affected the high level of people's satisfaction.

\section{Discussion}

Based on this research's result in Kutai Kurtanegara, it indicates that the patients who obtain dental treatments in a health care center show highest number are women. Women and young adults visit the dental clinics more than man and elderly. Basically, there is no relation between the average value of the patients' expectation and their perception based on the categories of age, gender, education level, and marital status (Mthethwa \& Chabikuli, 2016).

An adult believes have a higher level of satisfaction towards a quality of service compared to youth because the older the person is, the more critical his or her way of thinking is, and they are able to assess something better. In this research, the patients with the age above 45 years old were as much as $39.7 \%$. There is only a small number of 
research that reports the relation of age and the patients' satisfaction in obtaining treatments. The most research stated that there is no significant relation associated with the age of the patient (Jalimun et al., 2014; Hasalli et al., 2014).

The higher education level of a person is, the bigger the chance to obtain information and knowledge is. Through the duration of education, the respondents or the patients will also obtain more information and knowledge compared to those who had never obtained an education, that in assessing the satisfaction of a service quality, knowledge will influence the attitude and behavior of a person. People who have low education level are not critical and even do not care about the health service that they obtained. The most respondents in this research were those of senior high school graduated, were 52.1\%. The small number of respondents with bachelor's degree education level was possible because the respondents were busy with their own business or other activities (Jalimun et al., 2014; Wang et al., 2015).

In this research, the best service quality was on the dimensions of doctor and pharmacy; $99.5 \%$ of the respondents felt that the service provided was good. This is in line with the research conducted by Maino et al., in 2017, which stated that the relation between the doctors, patients, and pharmacy staffs is positive and significant towards the quality of service and patients' satisfaction. A doctor who provides service should be discipline, give a clear explanation, and a sincere attitude towards the problems that the patients experience. In the other hand, the technical competence in giving treatments and the 24 hours availability of the doctors in health service center also influence the patients' satisfaction. A doctor should not only have the ability to give treatments or a good discipline, but he or she should also be able to establish a good relationship with the patients that the doctors can help the patients in facing their problems or illnesses (Warda et al., 2016; Maino et al., 2014).

Nurses and pharmacy staffs should give an excellent health service that it can create the patients' satisfaction towards the quality of service. Patients want trained staffs for giving information. Patients also want the health service providers to work as a collaborative team and an effective communication in order to give a good service quality. Therefore, in order to guarantee an optimal quality of service, the health service provider has to be more aware and responsive towards the patients' satisfaction because it is one of the factors that can help increasing the result of provided treatments (Hasali et al., 2014; Mainoo et al., 2014).

The medical staffs are the take an important role in a service system. Medical staffs are expected to be fast, polite, and efficient in doing their operational tasks in helping the patients. The administration or registration staffs work in giving administrative service for the patients. The administration procedure in the health service center includes the process of registration, hospitalization, waiting for consultation, and paying for the treatment. The easiness of administration procedure is important in ensuring the patients' satisfaction towards a service quality in the hospital (Warda et al., 2016; Ratnam, 2015).

The environment of the health service center can indirectly become a parameter in seeing the quality of health service. In this research, the environment of the health service center had the highest number of respondents who felt dissatisfied with the service provided. Basically, an environment is associated with tools, the appearance of health service center, the facility provided, the availability of a resource, and the comfort of the environment. The facilities influencing the environment is provided by the service provider, such as parking lot, and interior instrumentation such as information board, maps of the health service center, recycle bins and medical waste. In this research, only the factor of environment that did not have significant relation towards the patients' satisfaction, which means that even though the quality of the environment of the health service center is still low, it did not influence the patients' satisfaction in obtaining the health service (Bahari \& Aziza, 2013).

The better of quality service increase the satisfaction level. The patients' perception of a good service quality is believed to influence their satisfaction, which respectively influences their decision to choose a certain health service provider. Patients' satisfaction is a common factor in determining health service center. Many efforts can be done in increasing the quality of health service, from the side of quality improvement of either the staffs or the facility and the environment around the health service, that such good service quality can create healthy and prosperous people (Fraihi, 2016).

In this global era competition, health service providers have to be successful in improving their process of service. Therefore, it is very important to know the way to improve the quality of all service dimensions which meets the expectation and perception of the patients. Doctors' behavior has an important role regarding the patients' satisfaction; it is then followed by the availability of medicines, the infrastructure of health service center, staffs' attitude, and medical information. The main reason why patients return to a health facility is the satisfaction associated with the doctors, interaction with patients, nurses, and the facility of the health service center. Therefore, identifying the factors that can improve the patients' satisfaction is beneficial in order to improve the service 
quality; it is very important to do, especially in a health facility (Devi \& Muthuswamy, 2016; Makarem et al., 2016; Chang, 2013).

\section{Conclusion}

Patient satisfaction related to the health care services quality. A good service quality believes that to affect the people's satisfaction which generally affects people's decision to choose health service provider. Health service centers are expected to increase their environmental condition, and the professionalism of the nurses and registration officers in terms of their awareness and performance in order to create better services. Registration, doctors, nurses, pharmacy, and environmental health service center in Kutai Kartanegara Regency have a positive correlation on patient satisfaction.

\section{Competing Interests Statement}

The authors declare that there is no conflict of interests regarding the publication of this paper.

\section{References}

Ali, D. (2016). Patient satisfaction in Dental Health Care Centers. European Journal of Dentistry, 10(3), 309-13. https://doi.org/10.4103/1305-7456.184147

Alotaibi, M. (2016). Are the rural-urban differences in dentist supply. University of Kentucky.

Asefa, A., Kassa, A., \& Dessalegn, M. (2014). Patient Satisfaction with outpatient health service in Hawassa University teacing Hospital, Southern Ethiopia. Journal of Public Health and Epidemiology, 6(2). 101-110. https://doi.org/10.5897/JPHE2013.0613

Azizan, N. A., \& Bahari, M. (2013). The effects of preceived service quality on patient satisfaction at a public hospital in state of Pahang, Malaysia. Asian journal of social sciences \& humanities, 2(3), 307-10

Chang, W. J., \& Chang, Y. S. (2013). Patient satisfaction analysis : identifying key drivers and enhancing service quality of dental care. Journal of Dental Sciences, 8, 239-40. https://doi.org/10.1016/j.jds.2012.10.006

Devi, K. V., \& Muthuswamy, P. R. (2016). A study on service quality gap in multi-speciality hospital. Indian Journal of applied research, 6(12).

Dinas Kesehatan Provinsi Kalimantan Timur. (2013). Profil Kesehatan Provinsi Kalimantan Timur.

Edman K, et al. (2017). Attitudes to dental care, Sweden 2003-2013, and clinical correlates of oral health-related quality of life in 2013. Int J Dent Hygiene, 1(10). https://doi.org/10.1111/idh.12269

Fraihi K. (2016). Evaluation of outpatient service quality in Eastern Saudi Arabia. Saudi Med J, 37(4), 421-422. https://doi.org/10.15537/smj.2016.4.14835

Gharibi, M., Sanagouymoharer, G., \& Yaghoubinia, F. (2016). The relationship between quality of life with marital satisfaction in Nurses in social security hospital in Zahedan. Global Journal of Health Science, 8(2), 178-80. https://doi.org/10.5539/gjhs.v8n2p178

Gopal, R., \& Bedi, S. S. (2014). Impact of hospital service on outpatient satisfaction. IJRBM, 2(4), 37-44.

Hasalli, M. A., Alrasheedy, A. A., Ab Razak, R. A., AL-Tamimi, S. K., Saleem, F., Haq, N. U., \& Aljadhey, H. (2014). Assessment of general public satisfaction with public health care service in Kedah Malaysia. Atustralian Medical Journal, 7(1), 35-44. https://doi.org/10.4066/AMJ.2014.1936

Hidayat, H. T. (2016). Pengaruh kualitas pelayanan, persepsi tentang biaya dan citra terhadap kepuasan dan loyalitas pengguna (studi pada instansi rawat jalan RSUD Dr. Saiful Anwar Malang). Jurnal Ilmiah Administrasi Publik, 2(2), 130-7.

Irfan, S. M., Ijaz, A., Farooq, M. M. (2012). Patient satisfaction and service quality of public hospital in Pakistan: an empirical assessment. Middle-east journal of scientific research, 12(6), 870-2

Jalimun, Y. P., Widjanarko, B., Peitojo, H. (2014). Kepuasan pasien dibalai pengobatan gigi (BPG) puskesmas Kahuripan kota Tasikmalaya. Jurnal Kesehatan Komunitas Indonesia, 10(1)

Kutai Kartanegara dalam angka. (2016). Badan Pusat Statistik Kabupaten Kutai Kartanegara (pp. 3-9, 146-151).

Makarem, J. et al. (2016). Patients satisfaction with inpatient services provided in hospitals affiliated to Tehran University of Medical Sciences, Iran, during 2011-2013. Journal of Medical Ethics and History of Medicine, 9(6). Pp. 7-9

Mainoo, G. O., Addo, B., \& Boadi, A. G. (2014). TQM health practices and client satisfaction in a selected health 
facility in Ghana. IJM, 5(8), 47-56

Meymand, F. M., Aryankhezal, A., \& Raeissi, P. (2017). Relationship between quality of the referral chain of hospital service and patient satisfaction. Global journal of health scence, 9(2), 68-70. http://dx.doi.org/10.5539/gjhs.v9n2p68

Mthethwa, S. R., \& Chabikuli, N. J. (2016). Comparing repeat and first visit patients' satisfaction with service quality at medunsa oral health centre. SADJ, 71(10), 454-8.

Parasuraman, A, Zeithmal, V. A., \& Berry, L. L. (1988). SERVQUAL: Multiple-itemscale for measuring consumerperceptions of service quality. J Retailing, 64(1). pp 12-40

Ratnam, E. (2015). Determinants of patients satisfaction in hospital. European Journal of Business and Management, 7(4), 63-65.

Sembel, M., Opod, H., \& Hutagalung, B. S. (2014). Gambaran tingkat kepuasan pasien terhadap perawatan gigi dan mulut di puskesmas Bahu. Jurnal e-GiGi, 2(2).

Tanudjaya PK. (2014). Pengaruh kualitas pelayanan klinik gigi terhadap kepuasan dan kepercayaan pasien sehingga meningkatkan keinginan untuk berobat kembali. Jurnal Manajemen dan Pemasaran Jasa, 7(1). 40-6.

Undang Undang Republik Indonesia Tentang Kesehatan Nomor 36 Tahun 2009. Kementrian Kesehatan Republik Indonesia [internet]. Retrieved from https:www.depkes.go.id

Wang, W., Shi, L., Yin, A., Mao, Z., Maitland, E., Nicholas, S., \& Liu, X. (2015). Primary care quality among different health care structures in Tibet China. Biomed Research International, 1-3 https://doi.org/10.1155/2015/206709

Warda, A., Junaid, \& Fachievy, A. F. (2016). Hubungan persepsi mutu pelayanan dengan tingkat kepuasan pasien puskesmas perumnas di kota Kendari. Universitas Haluoleo, 3-4.

World Health Organization. (2013). Oral helath surveys basic methods fifth edition. WHO library cataloguing in publication data, 19-20.

\section{Copyrights}

Copyright for this article is retained by the author(s), with first publication rights granted to the journal.

This is an open-access article distributed under the terms and conditions of the Creative Commons Attribution license (http://creativecommons.org/licenses/by/4.0/). 